\title{
Magnesium Can Protect against Vanadium-Induced Lipid Peroxidation in the Hepatic Tissue
}

\author{
Agnieszka Ścibior, ${ }^{1,2}$ Dorota Gołębiowska, ${ }^{1}$ and Irmina Niedźwiecka ${ }^{1}$ \\ ${ }^{1}$ Department of Zoology and Invertebrate Ecology, Laboratory of Physiology and Animal Biochemistry, \\ The John Paul II Catholic University of Lublin, 102 Kraśnicka Avenue, 20-718 Lublin, Poland \\ ${ }^{2}$ Centre of Interdisciplinary Research, Laboratory of Oxidative Stress, The John Paul II Catholic University of Lublin, \\ 102 Kraśnicka Avenue, 20-718 Lublin, Poland
}

Correspondence should be addressed to Agnieszka Ścibior; cellbiol@kul.lublin.pl

Received 3 February 2013; Revised 7 April 2013; Accepted 8 April 2013

Academic Editor: Kota V. Ramana

Copyright (c) 2013 Agnieszka Ścibior et al. This is an open access article distributed under the Creative Commons Attribution License, which permits unrestricted use, distribution, and reproduction in any medium, provided the original work is properly cited.

\begin{abstract}
The protective effect of magnesium as magnesium sulfate (MS) on sodium-metavanadate- (SMV-) induced lipid peroxidation (LPO) under in vivo and in vitro conditions was studied. The 18 -week SMV intoxication (Group II, $0.125 \mathrm{~V}_{\text {end }} / \mathrm{mL}$ ) enhanced spontaneous malondialdehyde (MDA) generation in rat liver, compared with the control (Group I) and MS-supplemented animals (Group III, $0.06 \mathrm{Mg}_{\text {end }} / \mathrm{mL}$ ). Coadministration of SMV with MS (Group IV, SMV-MS) caused a return of the MDA level to the control value range. The effect seems to result from the $\mathrm{Mg}_{\text {end }}$-independent action and its antagonistic interaction with $\mathrm{V}_{\text {end. }}$. The in vitro treatment of liver supernatants (LS) obtained from all the tested animals groups with selected exogenous concentrations of $\mathrm{Fe}_{\text {exg }}$ or $\mathrm{V}_{\text {exg }}$ exhibited enhanced MDA production, compared with spontaneously formed MDA. It also showed $\mathrm{Mg}_{\text {exg }}$-stimulating effect on LPO (LS I, Group I) and revealed that the changes in the MDA generation in LS IV (Group IV) might have resulted from the synergistic interactions of $\mathrm{V}_{\text {end }}$ with $\mathrm{Fe}_{\text {exg }}$ and $\mathrm{V}_{\text {exg }}$ and from the antagonistic interactions of $\mathrm{Mg}_{\text {end }}$ with $\mathrm{Fe}_{\text {exg }}$ and $\mathrm{V}_{\text {exg }}$. The findings allow a suggestion that adequate $\mathrm{Mg}$ intake for a specific period in the conditions of SMV exposure may prevent V-induced LPO in the liver.
\end{abstract}

\section{Introduction}

Lipid peroxidation (LPO) is a well-known free-radical process defined as oxidative deterioration of lipids. It is used as an indicator of oxidative stress (OS), which occurs when the balance between the production of reactive oxygen species (ROS) and free radicals (FR) overrides the antioxidant capability of the cells or tissues [1-3]. It may be one of the possible mechanisms underlying oxidative cellular damage caused by ROS, and it can be implicated in the pathogenesis of a number of diseases $[2,4]$. The products formed during LPO such as aldehydes, inter alia, and malondialdehyde (MDA) are well known to have deleterious effects. They can alter biological membrane organization and modify proteins and DNA. On the other hand, they can also modulate signal transduction pathways, induce adaptive response, as well as increase tolerance against forthcoming OS by upregulating defense capacity $[5,6]$.

Vanadium (V), which is a widely distributed element, has a wide range of industrial use. It interplays environmentally, occupationally, and biologically with human life [7]. Its toxicity depends, inter alia, on the route of administration, chemical form, and oxidation state, which determines the extensive biological effects of this element [8]. Due to its harmful health effects [9], our particular interest has been focused on searching factors which might prevent the deleterious action of $\mathrm{V}$ and attenuate its prooxidant activity.

As a redox-active metal, $\mathrm{V}$ may modulate the cellular redox potential and be involved in oxidative injury mechanisms. In certain conditions, it may enhance the generation of oxygen-derived reactive species and stimulate LPO [10]. Its prooxidant properties have been revealed in in vivo and 
in vitro conditions both by us $[11,12]$ and by some other researchers [10,13-21]. On the other hand, antioxidant action of $\mathrm{V}$ [22], its insulin-like effects [23], and anticarcinogenic activity [24-26] have also been reported.

In turn, the relatively non-toxic and nonredox reactive magnesium $(\mathrm{Mg})$ cannot participate in redox reactions that yield FR. It may effectively protect against FR and peroxidative damage. Its inhibitory effects on LPO have been demonstrated in vitro $[27,28]$ and in vivo in various animal models, including rats, [29-32] as well as in human studies $[33,34]$. The limitation of LPO by this element has also been revealed under the conditions of cadmium and mercury exposure in a rat model $[35,35]$. However, in some conditions $\mathrm{Mg}$ may stimulate LPO causing OS. Its ability to elevate LPO has been revealed by us [11, 12] and by some other investigators [27].

The antioxidant potential of $\mathrm{Mg}$ and its beneficial role in limiting LPO and the strong prooxidant potential of $\mathrm{V}$ and its well-known toxicological impact as well as insufficient information about the possible protective influence of $\mathrm{Mg}$ on $\mathrm{V}$-induced LPO prompted us to perform an experiment in a rat model to explore the hypothesis whether an 18-week administration of $\mathrm{Mg}$ as magnesium sulfate $\left(\mathrm{MgSO}_{4}, \mathrm{MS}\right.$, $0.06 \mathrm{mg} \mathrm{Mg} / \mathrm{mL}$ ) in combination with sodium metavanadate $\left(\mathrm{NaVO}_{3}, \mathrm{SMV}\right)$ will be able to effectively limit V-stimulated LPO in the liver. This organ is one of the sites of $\mathrm{V}$ accumulation and plays a major role in the storage, secretion and production of many important substances as well as in maintenance of homeostasis and detoxification allowing the body to function and live. The influence of exogenous $\mathrm{Mg}$, $\mathrm{V}$ and Fe on LPO in liver supernatants (LS) and the effects of interactions between them, recognition of which may help in elucidation of the cellular mechanisms of the response to combinations of metals, have also been examined.

\section{Material and Methods}

2.1. Chemicals and Reagents. $\mathrm{NaVO}_{3}(\mathrm{SMV}),\left(\mathrm{MgSO}_{4}, \mathrm{MS}\right)$, iron sulfate $\left(\mathrm{FeSO}_{4}\right)$, and thiobarbituric acid (TBA) were obtained from Sigma Chemicals (St. Louis, MO, USA). All the other chemicals and reagents used were of analytical grade.

2.2. Experimental Design. The experiment was conducted on 40 adult outbred albino male Wistar rats with average initial body weight about $267 \mathrm{~g}$, which, following an adaptation period of 7 days in a room in controlled conventional conditions, were randomly divided into 4 groups (10 rats per group). All the rats were individually housed in stainless steel cages (one rat per cage) when the experiment was started. Every day over a 18-week period, all the rats had unlimited access to the rodent laboratory chow (Labofeed B; Fodder and Concentrate Factory, Kcynia, Poland) in the shape of pellets of $12 \mathrm{~mm}$ diameter and they received to drink: Group I (untreated control)—deionized water; Group II (SMV)—a water solution of $\mathrm{NaVO}_{3}$ at a concentration of $0.125 \mathrm{mg} \mathrm{V} / \mathrm{mL}$; Group III (MS) a water solution of $\mathrm{MgSO}_{4}$ at a concentration of $0.06 \mathrm{mg} \mathrm{Mg} / \mathrm{mL}$; Group IV (SMV-MS) - a water solution of $\mathrm{NaVO}_{3}$ and $\mathrm{MgSO}_{4}$ at the same concentrations as in Group
II for $\mathrm{NaVO}_{3}$ and in Group III for $\mathrm{MgSO}_{4}$. Food, fluids, and deionized water were offered ad libitum. Throughout the 18weeks period, body weight was obtained weekly and at the time of slaughter. Animals' behavior was also observed.

The stock solutions of $\mathrm{NaVO}_{3}$ and $\mathrm{MgSO}_{4}$ were replaced by freshly prepared solutions every 2 days. The daily intake of water and the solutions of SMV, MS, and SMV-MS were measured with a measuring cylinder and the water and fluid intake was expressed as $\mathrm{mL} / \mathrm{rat} / 24 \mathrm{~h}$. In turn, the daily intake of $\mathrm{V}$ and $\mathrm{Mg}$ in the SMV- or/and MS-administered animals was estimated on the basis of the $24 \mathrm{~h}$ consumption of the SMV, MS, and SMV-MS solutions and expressed as $\mathrm{mg} / \mathrm{kg}$ b.wt./24 h. However, the food intake was calculated on the basis of the $24 \mathrm{~h}$ consumption of food by the rats from all the groups (the remainder of food together with additional spillage was weighed and subtracted from the whole food that the rats received to eat) and expressed as $\mathrm{g} / \mathrm{rat} / 24 \mathrm{~h}$. The $\mathrm{V}$ and $\mathrm{Mg}$ concentrations in drinking water were selected on the basis of our previous experiments conducted in a rat model $[11,12,36]$ and studies of other researchers $[37,38]$. The concentration of $\mathrm{V}$ was chosen to reveal its prooxidant potential, which was meant to be attenuated by the administration of this element in combination with $\mathrm{Mg}$. The concentration of $\mathrm{Mg}$ was chosen to be not too high since $\mathrm{Mg}\left(\right.$ as $\mathrm{MgSO}_{4}$ ) has been reported to induce diarrhea [39, 40].

After 18 weeks, all the rats were sectioned between 8:00 and 11:00 am and livers, which were used to prepare LS for determination of the MDA level, and other organs were dissected, directly washed in ice-cold physiological saline solution $(0.9 \% \mathrm{NaCl})$, and weighed. The biological material that was not used immediately was stored frozen at $-20^{\circ} \mathrm{C}$ or $-80^{\circ} \mathrm{C}$ in a deep-freezer HFU 486 basic (bought as part of the Project entitled "Building of the Centre of Interdisciplinary Research" realized within the frame of the Operating Programme "Development of Eastern Poland" 2007-2013, Priority I: Modern Economy, Action I.3. The Advancement of Innovation, cofinanced by the European Regional Development Fund) (Thermo Fisher Scientific, Germany) until further analysis. The experiment was conducted according to the experimental protocol approved by the 1st Local Ethical Committee for Animal Studies in Lublin, Poland.

2.3. Analytical Procedure. LSs, in which the MDA level was determined using TBA, were obtained from 40 outbred 6.5month-old albino male Wistar rats. More details concerning the preparation of LS for measurement of MDA and the methodology of determination of this LPO marker have been described by us previously [11]. LSs obtained from all the groups of rats: LS I (from Group I, Control), LS II (from Group II, SMV), LS III (from Group III, MS), and LS IV (from Group IV, SMV-MS) were divided into a few parts and subsequently incubated (a) without an inductor: LPO spontaneous ( $\left.\mathrm{LPO}_{\text {spont. }}\right)$, (b) with $30 \mu \mathrm{M} \mathrm{FeSO} 4\left(\mathrm{Fe}_{\operatorname{exg} 30 \mu \mathrm{M}}\right)$, (c) with 100,200 , or $400 \mu \mathrm{M} \operatorname{SMV}\left(\mathrm{V}_{\operatorname{exg} 100,200,400 \mu \mathrm{M}}\right)$, or (d) with 100, 200, or $400 \mu \mathrm{M}$ MS $\left(\mathrm{Mg}_{\operatorname{exg} 100,200,400 \mu \mathrm{M}}\right)$. The MDA formed was calculated using the molar extinction coefficient $1.56 \times 10^{5} \mathrm{M}^{-1} \mathrm{~cm}^{-1}$ and the results were expressed in nmoles per gram of wet tissue ( $\mathrm{nmol} / \mathrm{g}$ wet tissue). 
TABLE 1: Main and interactive effects of $\mathrm{V}_{\text {end }}$ and $\mathrm{Mg}_{\text {end }}$ on the measured variables in male Wistar rats after 18-week administration of both elements as SMV and MS in combination.

\begin{tabular}{|c|c|c|c|c|}
\hline \multirow{2}{*}{ Variables $^{\mathrm{a}}$} & \multicolumn{3}{|c|}{ Two-way ANOVA analysis ${ }^{\mathrm{b}}$} & \multirow{2}{*}{ Character of interaction revealed } \\
\hline & Main effect of $V_{\text {end }}$ & Main effect of $\mathrm{Mg}_{\text {end }}$ & Interactive effect of $\mathrm{V}_{\text {end }} \times \mathrm{Mg}_{\text {end }}$ & \\
\hline Fluid I & $F=61.263, P=0.000$ & NS & NS & - \\
\hline Food I & $F=45.645, P=0.000$ & NS & NS & - \\
\hline BWG & $F=46.591, P=0.000$ & NS & NS & - \\
\hline $\mathrm{LPO}_{\text {spontaneous }}$ & $F=22.678, P=0.000$ & $F=21.722, P=0.000$ & $F=9.091, P=0.005$ & Antagonistic \\
\hline
\end{tabular}

${ }^{a}$ Fluid I and Food I: fluid and food intake expressed as $\mathrm{mL}$ and $\mathrm{g} / \mathrm{rat} / 24 \mathrm{~h}$, respectively; BWG: body weight gain expressed as g/18 week.

${ }^{\mathrm{b}}$ Data are presented as $F$ values and the levels of significance $(P)$. NS: no significant effect.

${ }^{c}$ The effect of $\mathrm{V}_{\text {end }}$ and $\mathrm{Mg}_{\text {end }}$ in combination $\left(\mathrm{V}_{\text {end }}+\mathrm{Mg}_{\text {end }}\right.$ effect $)<$ or $>$ sum of the effects of $\mathrm{V}_{\text {end }}$ and $\mathrm{Mg}_{\text {end }}$ alone $\left(\mathrm{V}_{\text {end }}\right.$ effect $+\mathrm{Mg}_{\text {end }}$ effect $)($ antagonistic or synergistic interaction, resp.).

2.4. Statistical Analysis. The results were processed with the Statistica and SPSS, version 9.0 and 14.0 PL for Windows, respectively. The distribution patterns in the data were evaluated using the Shapiro-Wilk's normality test. The homogeneity of variances was verified employing Levene's test and sometimes also Hartley's Fmax, Cochran's C and Bartlett's tests. The two-way analysis of variance (2-way ANOVA) with the vanadium $\left(\mathrm{V}_{\text {end }}\right)$ and magnesium $\left(\mathrm{Mg}_{\text {end }}\right)$ factors and the $F$ test were employed to indicate the significant effects of $\mathrm{V}_{\text {end }}, \mathrm{Mg}_{\text {end }}$, or the $\mathrm{V}_{\text {end }} \times \mathrm{Mg}_{\text {end }}$ interaction. In addition, the three-way ANOVA analysis of variance (3way ANOVA) with exogenous iron $\left(\mathrm{Fe}_{\operatorname{exg} 30 \mu \mathrm{M}}\right)$, exogenous vanadium $\left(\mathrm{V}_{\text {exg } 100,200,400 \mu \mathrm{M}}\right)$, and exogenous magnesium $\left(\mathrm{Mg}_{\operatorname{exg} 100,200,400 \mu \mathrm{M}}\right)$ factors as well as the $F$ test were also employed to reveal significant effects of $\mathrm{Fe}_{\mathrm{exg}} 30 \mu \mathrm{M}$, $\mathrm{V}_{\text {exg } 100,200,400 \mu \mathrm{M}}$, or $\mathrm{Mg}_{\operatorname{exg} 100,200,400 \mu \mathrm{M}}$. F values which had $P$ values smaller than 0.05 were considered statistically significant. If the 2- or 3-way ANOVA tests demonstrated interactive effects between the elements used or trends toward those effects, subsequent calculations were done in order to describe the character of the interactions revealed (antagonistic or synergistic) [41]. The post hoc comparisons between the four individual groups were performed using Tukey's or T3 Dunnett's tests. Comparisons between spontaneous LPO and LPO modified exogenously by $\mathrm{Fe}_{\text {exg }}, \mathrm{V}_{\text {exg }}$ and $\mathrm{Mg}_{\text {exg }}$ were assessed by the $t$-test or Wilcoxon test for dependent samples. The Student's " $t$ "-test for independent samples was also applied for the detection of significant differences in the consumed $\mathrm{V}$ doses between the rats in Groups II and IV and Mg doses between the rats in Groups III and IV. The differences were considered significant if the $P$ values were smaller than 0.05 . All the results are expressed as mean \pm SEM.

\section{Results}

3.1. General Observation. No distinct differences in the physical appearance and motor behavior were observed during the 18 experimental weeks in most of the rats receiving the SMV or/and MS solutions to drink, compared with the control. Some of the rats which drank the SMV and MS solutions separately (Groups II and III, resp.) and in combination (Group IV) had gastrointestinal disturbances, which were probably caused by the ingestion of $\mathrm{V}$ or/and $\mathrm{Mg}$. Only one rat from Group IV had one-day diarrhea in the third and eight week of the experiment. In turn, loose stool was observed in one rat in Group II and in three rats in Groups III and IV in the first or/and second week of the experiment. However, in two rats in Group II and in one in Group III loose stool was observed at the turn of fifth and sixth week of the experiment and at the turn of second and fifth week of the study, respectively.

3.2. Basic Parameters. The fluid and food intakes as well as body weight gain in the rats of Groups II and IV were lower, compared with those found in the animals in Groups I and III (Figures 1(a), 1(c), and 1(d)). As the two-way ANOVA revealed, the decrease in the abovementioned parameters observed in the rats of Group IV was due to the independent action of $\mathrm{V}$ only (Table 1). It was also observed that the rats in Group IV took up slightly less V (by 8\%), in comparison with the animals in Group II, but this difference did not turn out to be statistically significant. In turn, the consumption of $\mathrm{Mg}$ by the rats in Group IV was significantly lowered (by $21 \%)$, compared with that found in the animals in Group III (Figure 1(b)), which might be an effect of reduced fluid intake due to the SMV administration (Figure 1(a)).

3.3. Spontaneously Formed Hepatic MDA. As presented in Figure 2(a), the exposure to SMV alone (Group II) significantly enhanced the level of spontaneously generated MDA, compared with the control (Group I), the MS-supplemented (Group III) and the SMV-MS-applicated (Group IV) rats. Supplementation of the rats with MS alone did not change markedly the MDA formation, compared with the control, whereas the administration of MS in combination with SMV reduced its level by $62 \%$, compared with the SMV-intoxicated rats. It was also observed that the level of the examined LPO marker was within the same value range that was found in the control animals. The two-way ANOVA revealed that the decrease in the spontaneously formed MDA in the rats of Group IV was influenced by the independent action of $\mathrm{Mg}$ and by its interaction with $\mathrm{V}$ (Table 1 ).

3.4. MDA Level Modified by $\mathrm{Fe}_{\text {exg }}, V_{\text {exg }}$, and $M g_{\text {exg. }}$. In LS II, the MDA level modified by $\mathrm{Fe}_{\operatorname{exg} 30 \mu \mathrm{M}}$ (Figure 2(b)), $\mathrm{V}_{\text {exg 100, 200, } 400 \mu \mathrm{M}}$ (Figures 2(c), 2(d), and 2(e)) or $\mathrm{Mg}_{\text {exg 100, 200, } 400 \mu \mathrm{M}}$ (Figures 2(f), 2(g), and 2(h)) increased 


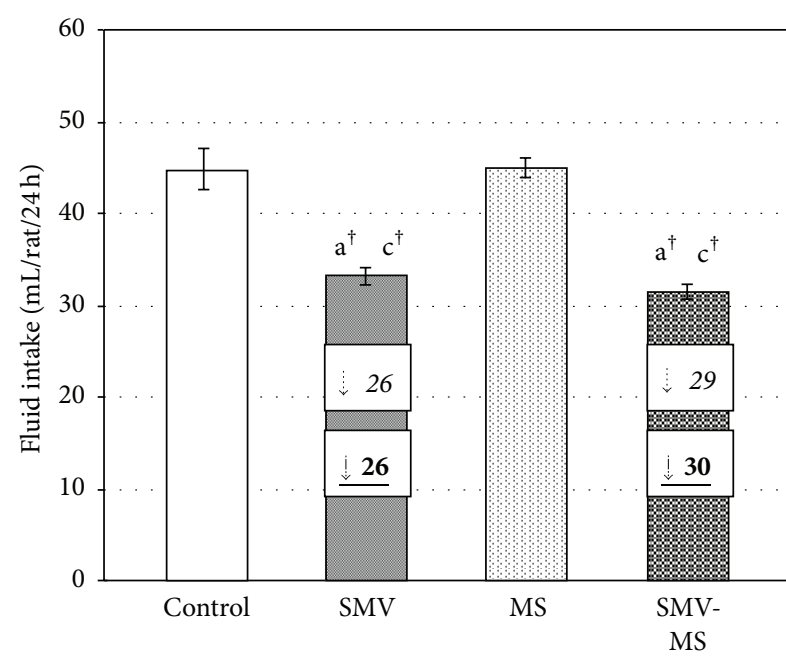

$(a)^{1}$

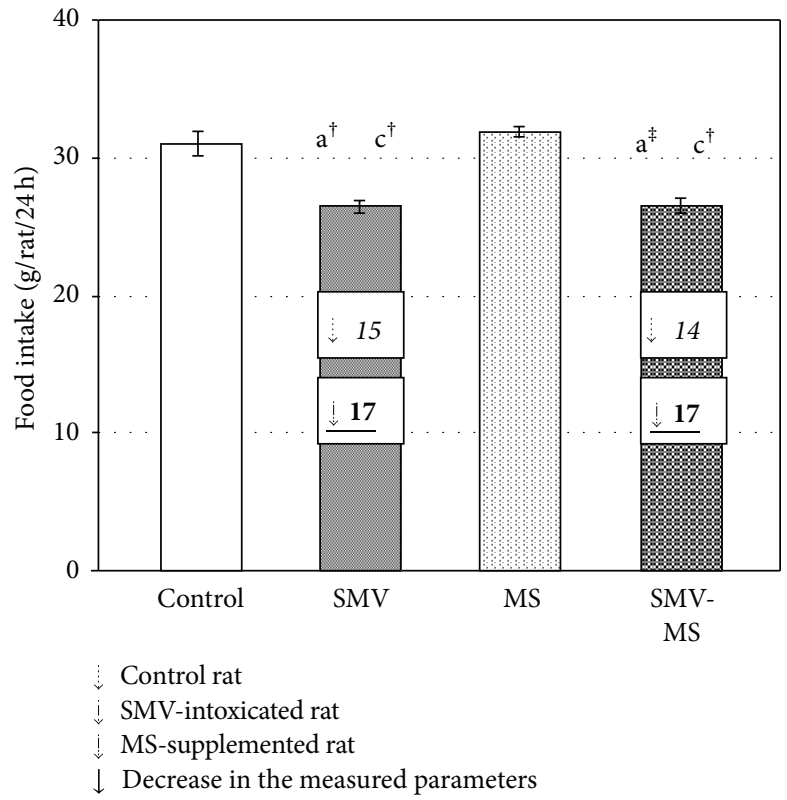

$(\mathrm{c})^{1}$

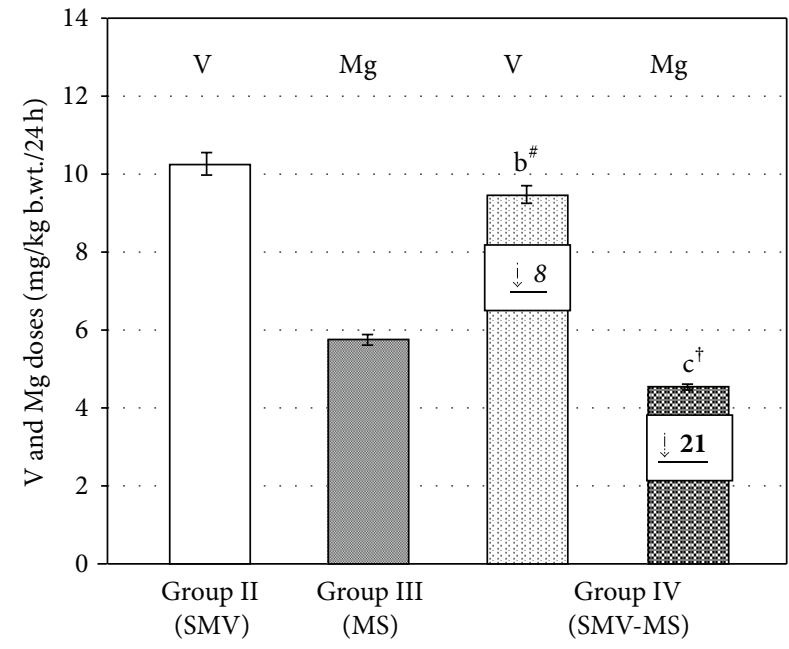

$(\mathrm{b})^{3}$

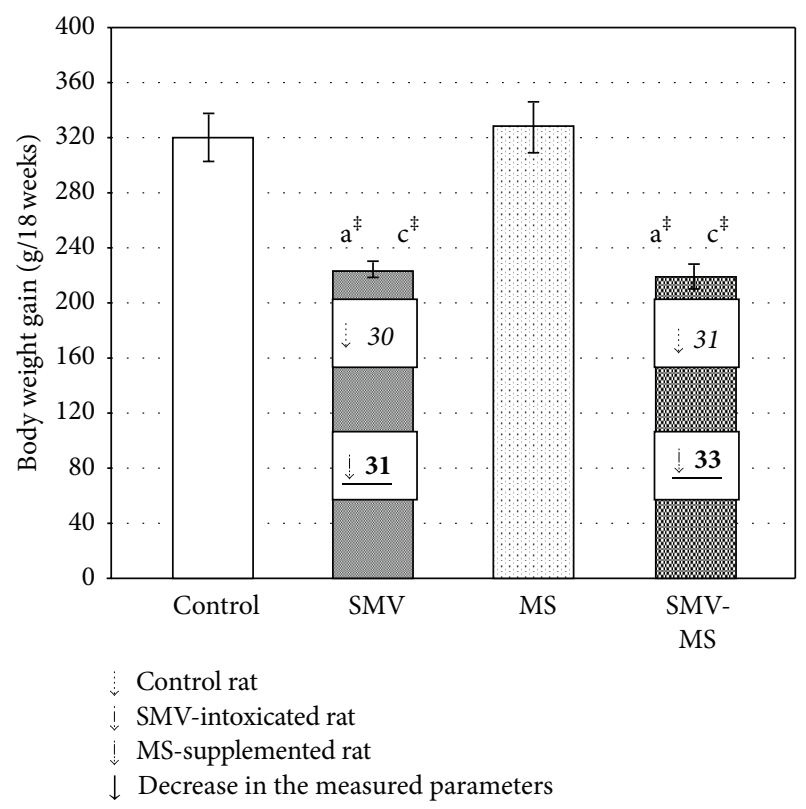

$(\mathrm{d})^{2}$

Figure 1: Fluid intake (a), V and Mg doses consumed by the rats through drinking water (b), food intake (c) and body weight gain (d) in the tested animals groups. Differences are indicated by ${ }^{\mathrm{a}, \mathrm{b}, \mathrm{c}}$ versus control, SMV-intoxicated and MS-supplemented rats, respectively $\left({ }^{1,2,3}\right.$ Tukey's, T3 Dunnett's and $t$ test, resp.). ${ }^{*} P<0.05,{ }^{\ddagger} P<0.01,{ }^{\dagger} P<0.001,{ }^{\#} P=0.09$. Numerical values in the bars indicate the percentage of the decrease in the measured parameters $(\downarrow)$, compared with the control (italic alone), the SMV-intoxicated (italic underline bold), and the MS-supplemented (underline bold) rats.

markedly, compared with that found in LS I, III, and IV incubated in the same in vitro conditions. Further, in LS IV incubated with the concentrations of $\mathrm{Fe}_{\operatorname{exg}} 30 \mu \mathrm{M}$, $\mathrm{V}_{\text {exg } 100,200,400 \mu \mathrm{M}}$, or $\mathrm{Mg}_{\operatorname{exg} 100,200,400 \mu \mathrm{M}}$, the level of MDA was markedly decreased by $76 \%, 38.5 \%, 29 \%, 22 \%$, $53 \%, 51 \%$, and $48 \%$, respectively, in comparison with that found in LS II incubated in the same manner (Figures 2(b)-2(h)). Moreover, in LS IV incubated with $\mathrm{Fe}_{\text {exg }} 30 \mu \mathrm{M}$ (Figure 2(b)) or with $\mathrm{Mg}_{\text {exg 100, 200, } 400 \mu \mathrm{M}}$ (Figures 2(f)-2(h)), the MDA level returned to the range of values obtained for LS I incubated with the same concentrations of $\mathrm{Fe}_{\mathrm{exg}}$ and $\mathrm{Mg}_{\text {exg }}$. In the presence of $\mathrm{V}_{\text {exg } 100 \mu \mathrm{M}}$ or $\mathrm{V}_{\text {exg } 200 \mu \mathrm{M}}$
(Figures 2(c) and 2(d)), the level of this LPO marker was not significantly elevated, compared with that demonstrated in LS I. Only in the presence of the highest V concentration $\left(\mathrm{V}_{\text {exg } 400 \mu \mathrm{M}}\right)$, its level was significantly higher, compared with LS I (Figure 2(e)). Furthermore, in LS IV incubated with $\mathrm{V}_{\text {exg } 100,200,400 \mu \mathrm{M}}$ (Figures 2(c), 2(d) and 2(e)), the MDA level was also significantly higher, compared with that found in LS III incubated in the presence of the abovementioned $\mathrm{V}_{\text {exg }}$ concentrations.

It was also shown that in LS III incubated in the presence of $\mathrm{Fe}_{\operatorname{exg}} 30 \mu \mathrm{M}$ (Figure 2(b)), $\mathrm{V}_{\text {exg } 100 \mu \mathrm{M}}$ (Figure 2(c)), or $\mathrm{Mg}_{\text {exg 100, } 400 \mu \mathrm{M}}$ (Figures 2(f) and 2(h)), the level of MDA 


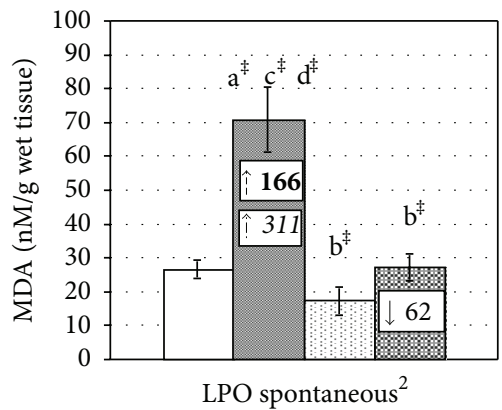

(a)

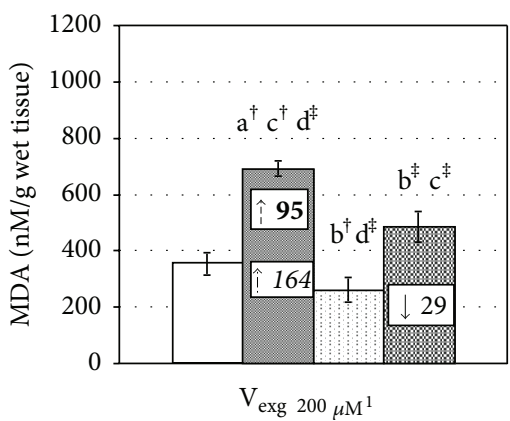

(d)

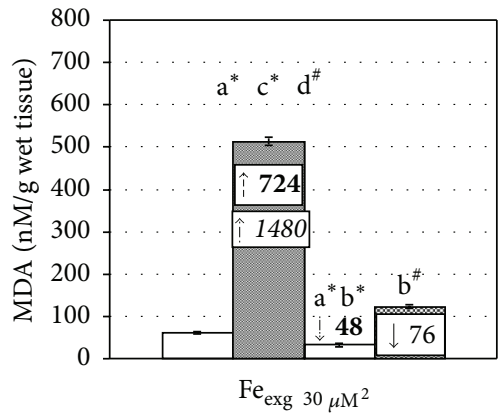

(b)

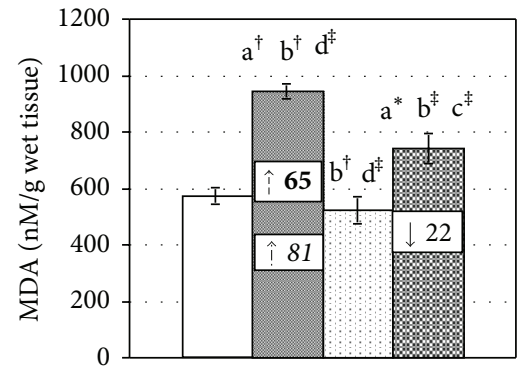

$\mathrm{V}_{\operatorname{exg}} 400 \mu \mathrm{M}^{1}$

(e)

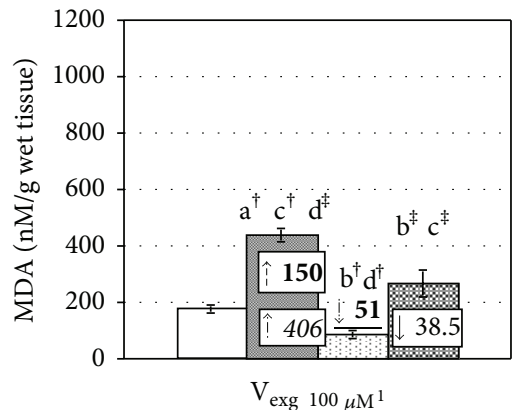

(c)

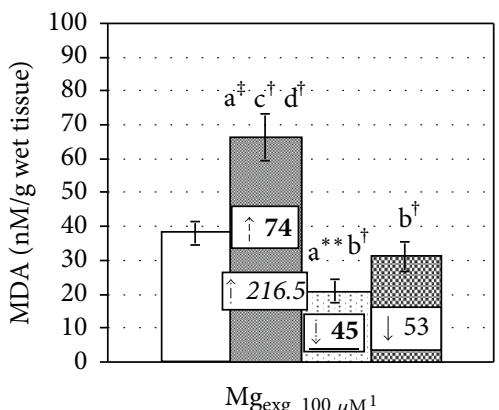

(f)
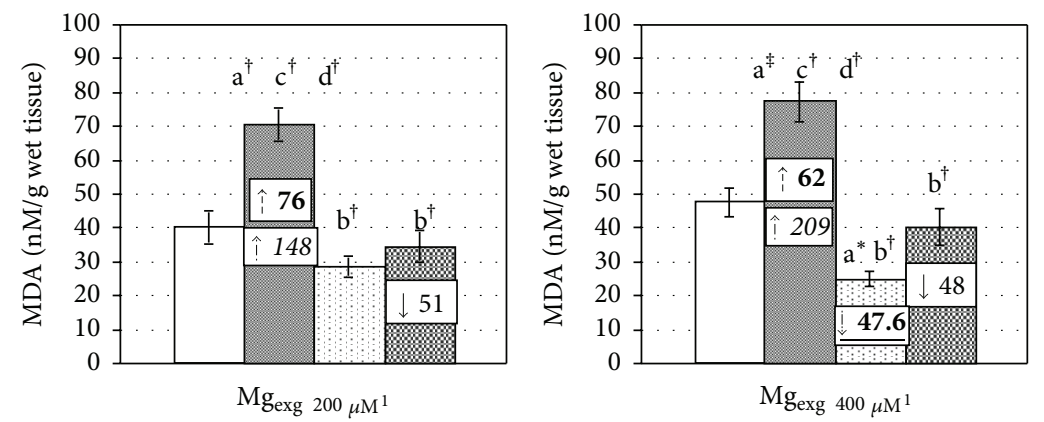

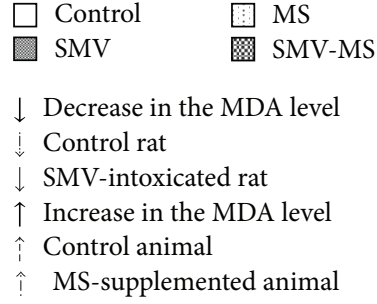

(g)

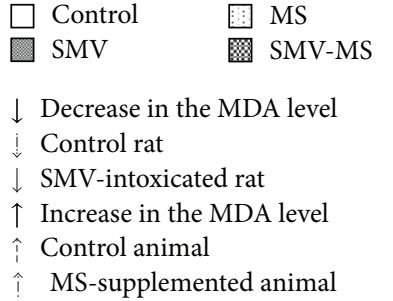

(h)

FIGURE 2: MDA level in LS obtained from the control, SMV-, MS- and SMV-MS-administered rats incubated without an oxidation inductor (LPO spontaneous) (a) or with $\mathrm{Fe}_{\text {exg } 30 \mu \mathrm{M}}\left(\mathrm{FeSO}_{4}\right)(\mathrm{b}), \mathrm{V}_{\text {exg 100, 200, } 400 \mu \mathrm{M}}\left(\mathrm{NaVO}_{3}\right)(\mathrm{c}, \mathrm{d}, \mathrm{e})$, or $\mathrm{Mg}_{\text {exg }}$ 100, 200, $400 \mu \mathrm{M}\left(\mathrm{MgSO}_{4}\right)(\mathrm{f}, \mathrm{g}$, h). Differences are indicated by ${ }^{\mathrm{a}, \mathrm{b}, \mathrm{c}, \mathrm{d}}$ versus control, SMV-intoxicated, MS-supplemented, and SMV-MS-administered rats, respectively $\left({ }^{1}\right.$ Tukey's and ${ }^{2} \mathrm{~T} 3$ Dunnett's test). ${ }^{*} P<0.05,{ }^{\ddagger} P<0.01,{ }^{\dagger} P<0.001,{ }^{* *} P=0.07,{ }^{\#} P=0.09,{ }^{\# \#} P=0.13$. Numerical values in the bars or above them indicate the percentage of the decrease in the MDA level $(\downarrow)$, compared with the control (underline bold) and the SMV-intoxicated (normal alone) rats; other numerical values in the bars indicate the percentage of the increase in the MDA level $(\uparrow)$, compared with the control (bold alone) and the MS-supplemented (bold italic) animals. 

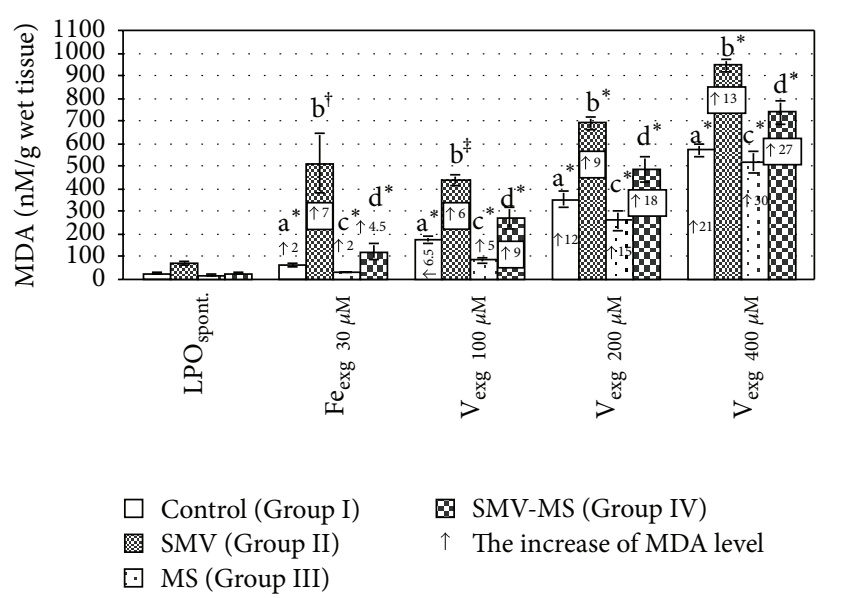

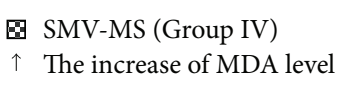

$\uparrow \quad$ The increase of MDA level

(a)
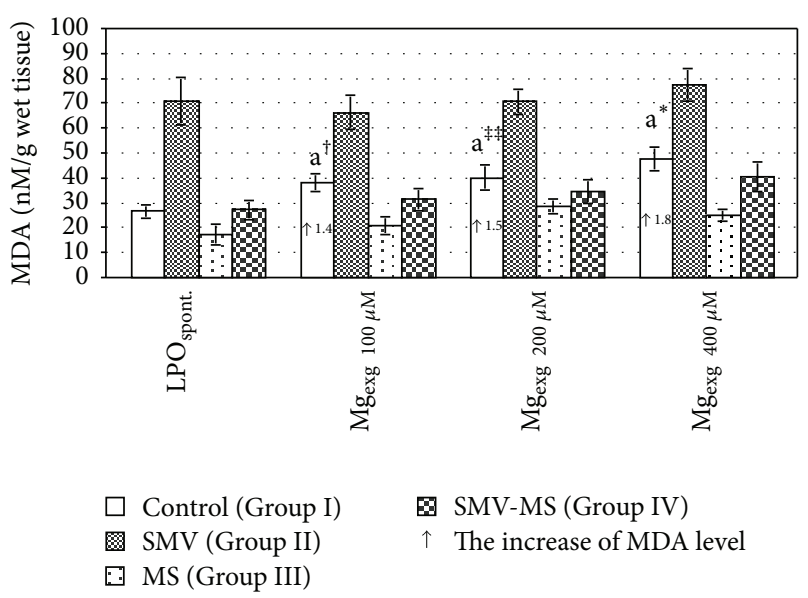

จ SMV-MS (Group IV)

$\uparrow$ The increase of MDA level

(b)

FIGURE 3: MDA level in LS obtained from the control, SMV-, MS- and SMV-MS-administered rats incubated without an oxidation inductor (LPO spontaneous) or with different exogenously added concentrations of $\mathrm{Fe}_{\operatorname{exg} 30 \mu \mathrm{M}}$ or $\mathrm{V}_{\operatorname{exg} 100,200,400 \mu \mathrm{M}}(\mathrm{a})$ or $\mathrm{Mg}_{\text {exg } 100,200,400 \mu \mathrm{M}}$ (b) as $\mathrm{FeSO}_{4}, \mathrm{NaVO}_{3}$ and $\mathrm{MgSO}_{4}$, respectively. Differences are indicated by ${ }^{\mathrm{a}, \mathrm{b}, \mathrm{c}, \mathrm{d}}$ versus $\mathrm{Control}_{\mathrm{LPO}}$ spont. $\mathrm{SMV}_{\mathrm{LPO} \text { spont. }}$, MS $\mathrm{LPO}_{\text {spont. }}$ and

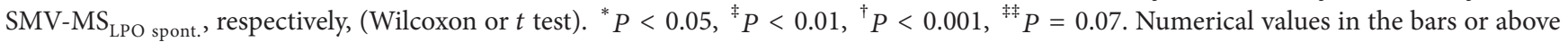
them indicate how many times the MDA level increased $(\uparrow)$.

was lowered by $48 \%, 51 \%, 45 \%$, and $47.6 \%$, respectively, in comparison with that in LS I incubated with the same concentrations of $\mathrm{Fe}_{\text {exg }}, \mathrm{V}_{\text {exg }}$, or $\mathrm{Mg}_{\text {exg }}$. The level of MDA in LS III incubated with $\mathrm{V}_{\text {exg } 200 \mu \mathrm{M}}, \mathrm{V}_{\operatorname{exg} 400 \mu \mathrm{M}}$ (Figures $2(\mathrm{~d}$ ) and 2(e)), or $\mathrm{Mg}_{\text {exg } 200 \mu \mathrm{M}}$ (Figure 2(g)) was also lower, compared with that observed in LS I, but these differences were not so clear.

In addition, LS I, obtained from the control rats, which were incubated with $\mathrm{Fe}_{\operatorname{exg} 30 \mu \mathrm{M}}, \mathrm{V}_{\operatorname{exg} 100,200,400 \mu \mathrm{M}}$ or $\mathrm{Mg}_{\text {exg } 100,200,400 \mu \mathrm{M}}$ exhibited higher MDA production, compared with that observed in LS I incubated without (Control LPO spont. $_{\text {( }}$ ) the abovementioned concentrations of $\mathrm{Fe}_{\text {exg }}$ or $\mathrm{V}_{\text {exg }}$ (Figure 3(a)) or $\mathrm{Mg}_{\text {exg }}$ (Figure 3(b)). Higher MDA production was also demonstrated in LS II, III, and IV obtained from the SMV-intoxicated, MS-supplemented, and SMV-MS-administered rats, respectively, incubated in the presence of $\mathrm{Fe}_{\mathrm{exg}} 30 \mu \mathrm{M}$ or $\mathrm{V}_{\operatorname{exg} 100,200,400 \mu \mathrm{M}}$, in comparison with the spontaneously formed MDA in those LSs (Figure 3(a)). In turn, the incubation of LS II, III, and IV in the presence of $\mathrm{Mg}_{\operatorname{exg} 100,200,400 \mu \mathrm{M}}$ did not significantly change the level of MDA, compared with $\mathrm{SMV}_{\mathrm{LPO} \text { spont. }}, \mathrm{MS}_{\mathrm{LPO} \text { spont. }}$, and SMV-MS $\mathrm{LPO}_{\text {spont. }}$, respectively (Figure 3(b)).

The three-way analysis of variance revealed that the changes in the MDA level in LS IV (obtained from the rats supplemented with MS during the SMV exposure)

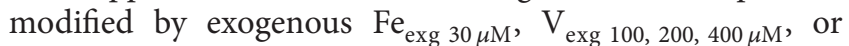
$\mathrm{Mg}_{\text {exg 100, 200, } 400 \mu \mathrm{M}}$ resulted from the independent action of $\mathrm{V}_{\text {end }}$ and $\mathrm{Mg}_{\text {end }}$ as well as from their interaction or a distinct trend toward the $\mathrm{V}_{\text {end }} \times \mathrm{Mg}_{\text {end }}$ interaction (Table 2). In addition, the three-way ANOVA indicated that, beside the effects revealed between $\mathrm{V}_{\text {end }}$ and $\mathrm{Mg}_{\text {end }}$, the alterations in the MDA production in LS IV incubated with $\mathrm{Fe}_{\text {exg } 30 \mu \mathrm{M}}$ were also a consequence of the independent action of $\mathrm{Fe}_{\text {exg }}$ and its interaction with $\mathrm{V}_{\text {end }}$ and $\mathrm{Mg}_{\text {end }}$ as well as an effect of the interaction between three elements: $\mathrm{Fe}_{\mathrm{exg}}, \mathrm{V}_{\text {end }}$, and $\mathrm{Mg}_{\text {end }}$. In turn, the changes in the MDA generation in LS IV incubated with $\mathrm{V}_{\operatorname{exg} 100 \mu \mathrm{M}}, \mathrm{V}_{\operatorname{exg} 200 \mu \mathrm{M}}$, or $\mathrm{V}_{\operatorname{exg} 400 \mu \mathrm{M}}$ additionally resulted from the independent action of $\mathrm{V}_{\operatorname{exg} 100 \mu \mathrm{M}}$, $\mathrm{V}_{\text {exg } 200 \mu \mathrm{M}}$, and $\mathrm{V}_{\operatorname{exg} 400 \mu \mathrm{M}}$ and from their interaction with $\mathrm{V}_{\text {end }}$ and $\mathrm{Mg}_{\text {end }}$ (Table 2). In the case of incubation of LS IV with $\mathrm{Mg}_{\operatorname{exg} 200 \mu \mathrm{M}}$ or $\mathrm{Mg}_{\operatorname{exg} 400 \mu \mathrm{M}}$, the three-way analysis of variance revealed that the alterations in the level of MDA in LS IV in the presence of $\mathrm{Mg}_{\text {exg } 200 \mu \mathrm{M}}$ or $\mathrm{Mg}_{\text {exg }} 400 \mu \mathrm{M}$ were also an effect of independent action of $\mathrm{Mg}_{\text {exg } 200 \mu \mathrm{M}}$ and $\mathrm{Mg}_{\text {exg } 400 \mu \mathrm{M}}$. In turn, any significant effect of $\mathrm{Mg}_{\text {exg } 100 \mu \mathrm{M}}$ on the MDA production in LS IV was revealed by the performed analysis (Table 2).

\section{Discussion}

The current report demonstrates the influence of the 18-week $\mathrm{V}$ and $\mathrm{Mg}$ administration (as SMV and MS, resp.), separately and in combination, on changes in such basic parameters as fluid and food intakes, and body weight gain in male Wistar rats. It also presents (a) the protective impact of $\mathrm{Mg}$ on the in vivo SMV-stimulated LPO in the rat liver, (b) the modulating effects of the exogenously used $\mathrm{Mg}, \mathrm{V}$, and $\mathrm{Fe}$ on LPO in in vitro conditions, (c) the main and interactive effects of the abovementioned elements, and (d) the character of their interactions with respect to changes in the explored free radical process.

On the basis of the data obtained, we may state that the supplementation of the rats with MS during the 18-week SMV exposure did not limit the decrease in the fluid and food intake and body weight gain (Figures 1(a), 1(c) and 1(d)). Similar effects had also been observed by us previously in rats supplemented with MS during the 12-week SMV exposure 
TABLE 2: Main and interactive effects of $\mathrm{V}_{\text {end }}, \mathrm{Mg}_{\text {end }}, \mathrm{Fe}_{\text {exg }}, \mathrm{V}_{\text {exg }}$ and $\mathrm{Mg}_{\text {exg }}$ on the MDA level measured in liver supernatants obtained from the SMV-MS coapplied rats incubated in in vitro conditions with $\mathrm{Fe}_{\operatorname{exg} 30 \mu \mathrm{M}}, \mathrm{V}_{\operatorname{exg} 100,200,400 \mu \mathrm{M}}$ or $\mathrm{Mg}_{\operatorname{exg} 100,200,400 \mu \mathrm{M}}$.

Three-way ANOVA analysis ${ }^{\mathrm{a}}$

\begin{tabular}{|c|c|c|}
\hline \multicolumn{2}{|l|}{ Three-way ANOVA analysis ${ }^{\mathrm{a}}$} & $\begin{array}{c}\text { Character of interaction revealed or character of a trend } \\
\text { toward interaction }\end{array}$ \\
\hline \multicolumn{3}{|l|}{ LPO modified by $\mathrm{Fe}_{\operatorname{exg} 30 \mu \mathrm{M}}$} \\
\hline Main effect of $V_{\text {end }}$ & $F=18.412, P=0.000$ & - \\
\hline Main effect of $\mathrm{Mg}_{\text {end }}$ & $F=11.626, P=0.001$ & - \\
\hline Interactive effect of $V_{\text {end }} \times \mathrm{Mg}_{\text {end }}$ & $F=8.097, P=0.006$ & Antagonistic ${ }^{\mathrm{b}}$ \\
\hline Main effect of $\mathrm{Fe}_{\operatorname{exg} 30 \mu \mathrm{M}}$ & $F=17.994, P=0.000$ & - \\
\hline Interactive effect of $\mathrm{Fe}_{\operatorname{exg} 30 \mu \mathrm{M}} \times \mathrm{V}_{\text {end }}$ & $F=12.317, P=0.001$ & Synergistic $^{c}$ \\
\hline Interactive effect of $\mathrm{Fe}_{\operatorname{exg} 30 \mu \mathrm{M}} \times \mathrm{Mg}_{\text {end }}$ & $F=6.995, P=0.010$ & Antagonistic $^{d}$ \\
\hline Interactive effect of $\mathrm{Fe}_{\operatorname{exg} 30 \mu \mathrm{M}} \times \mathrm{V}_{\text {end }} \times \mathrm{Mg}_{\text {end }}$ & $F=5.526, P=0.021$ & \\
\hline \multicolumn{3}{|l|}{ LPO modified by $\mathrm{V}_{\operatorname{exg} 100 \mu \mathrm{M}}$} \\
\hline Main effect of $\mathrm{V}_{\text {end }}$ & $F=75.402, P=0.000$ & - \\
\hline Main effect of $\mathrm{Mg}_{\text {end }}$ & $F=29.066, P=0.000$ & - \\
\hline Interactive effect of $V_{\text {end }} \times \mathrm{Mg}_{\text {end }}$ & $F=6.950, P=0.051$ & Antagonistic ${ }^{\mathrm{b}}$ \\
\hline Main effect of $\mathrm{V}_{\operatorname{exg} 100 \mu \mathrm{M}}$ & $F=206.252, P=0.000$ & - \\
\hline Interactive effect of $V_{\operatorname{exg} 100 \mu \mathrm{M}} \times \mathrm{V}_{\text {end }}$ & $F=46.205, P=0.000$ & Synergistic $^{\mathrm{e}}$ \\
\hline Interactive effect of $\mathrm{V}_{\text {exg } 100 \mu \mathrm{M}} \times \mathrm{Mg}_{\text {end }}$ & $F=12.570, P=0.001$ & Antagonistic ${ }^{f}$ \\
\hline Interactive effect of $\mathrm{V}_{\text {exg } 100 \mu \mathrm{M}} \times \mathrm{V}_{\text {end }} \times \mathrm{Mg}_{\text {end }}$ & NS & - \\
\hline \multicolumn{3}{|l|}{ LPO modified by $\mathrm{V}_{\operatorname{exg} 200 \mu \mathrm{M}}$} \\
\hline Main effect of $V_{\text {end }}$ & $F=51.672, P=0.000$ & - \\
\hline Main effect of $\mathrm{Mg}_{\text {end }}$ & $F=16.998, P=0.000$ & - \\
\hline Interactive effect of $V_{\text {end }} \times \mathrm{Mg}_{\text {end }}$ & $F=2.999, P=0.088$ & Antagonistic ${ }^{\mathrm{b}}$ \\
\hline Main effect of $\mathrm{V}_{\text {exg } 200 \mu \mathrm{M}}$ & $F=372.550, P=0.000$ & - \\
\hline Interactive effect of $\mathrm{V}_{\text {exg } 200 \mu \mathrm{M}} \times \mathrm{V}_{\text {end }}$ & $F=35.037, P=0.000$ & Synergistic $^{\mathrm{e}}$ \\
\hline Interactive effect of $\mathrm{V}_{\operatorname{exg} 200 \mu \mathrm{M}} \times \mathrm{Mg}_{\text {end }}$ & $F=8.299, P=0.005$ & Antagonistic ${ }^{f}$ \\
\hline Interactive effect of $\mathrm{V}_{\text {exg } 200 \mu \mathrm{M}} \times \mathrm{V}_{\text {end }} \times \mathrm{Mg}_{\text {end }}$ & NS & - \\
\hline \multicolumn{3}{|l|}{ LPO modified by $\mathrm{V}_{\text {exg } 400 \mu \mathrm{M}}$} \\
\hline Main effect of $\mathrm{V}_{\text {end }}$ & $F=61.594, P=0.000$ & - \\
\hline Main effect of $\mathrm{Mg}_{\text {end }}$ & $F=14.220, P=0.000$ & - \\
\hline Interactive effect of $V_{\text {end }} \times \mathrm{Mg}_{\text {end }}$ & $F=5.271, P=0.025$ & Antagonistic ${ }^{\mathrm{b}}$ \\
\hline Main effect of $\mathrm{V}_{\operatorname{exg} 400 \mu \mathrm{M}}$ & $F=1026.907, P=0.000$ & - \\
\hline Interactive effect of $V_{\operatorname{exg} 400 \mu \mathrm{M}} \times V_{\text {end }}$ & $F=42.650, P=0.000$ & Synergistic $^{\mathrm{e}}$ \\
\hline Interactive effect of $\mathrm{V}_{\text {exg } 400 \mu \mathrm{M}} \times \mathrm{Mg}_{\text {end }}$ & $F=6.158, P=0.015$ & Antagonistic ${ }^{\mathrm{f}}$ \\
\hline Interactive effect of $\mathrm{V}_{\mathrm{exg} 400 \mu \mathrm{M}} \times \mathrm{V}_{\text {end }} \times \mathrm{Mg}_{\text {end }}$ & NS & - \\
\hline \multicolumn{3}{|l|}{ LPO modified by $\mathrm{Mg}_{\operatorname{exg} 100 \mu \mathrm{M}}$} \\
\hline Main effect of $\mathrm{V}_{\text {end }}$ & $F=38.869, P=0.000$ & - \\
\hline Main effect of $\mathrm{Mg}_{\text {end }}$ & $F=49.991, P=0.000$ & - \\
\hline Interactive effect of $\mathrm{V}_{\text {end }} \times \mathrm{Mg}_{\text {end }}$ & $F=12.331, P=0.001$ & Antagonistic $^{\mathrm{b}}$ \\
\hline Main effect of $\mathrm{Mg}_{\operatorname{exg} 100 \mu \mathrm{M}}$ & NS & - \\
\hline Interactive effect of $\mathrm{Mg}_{\operatorname{exg} 100 \mu \mathrm{M}} \times \mathrm{V}_{\text {end }}$ & NS & - \\
\hline Interactive effect of $\mathrm{Mg}_{\operatorname{exg} 100 \mu \mathrm{M}} \times \mathrm{Mg}_{\text {end }}$ & NS & - \\
\hline Interactive effect of $\mathrm{Mg}_{\operatorname{exg} 100 \mu \mathrm{M}} \times \mathrm{V}_{\text {end }} \times \mathrm{Mg}_{\text {end }}$ & NS & - \\
\hline LPO modified by $\mathrm{Mg}_{\operatorname{exg} 200 \mu \mathrm{M}}$ & & - \\
\hline Main effect of $\mathrm{V}_{\text {end }}$ & $F=39.615, P=0.000$ & - \\
\hline Main effect of $\mathrm{Mg}_{\text {end }}$ & $F=48.829, P=0.000$ & - \\
\hline Interactive effect of $V_{\text {end }} \times \mathrm{Mg}_{\text {end }}$ & $F=16.616, P=0.000$ & Antagonistic ${ }^{\mathrm{b}}$ \\
\hline Main effect of $\mathrm{Mg}_{\operatorname{exg} 200 \mu \mathrm{M}}$ & $F=4.838, P=0.031$ & - \\
\hline Interactive effect of $\mathrm{Mg}_{\operatorname{exg} 200 \mu \mathrm{M}} \times \mathrm{V}_{\text {end }}$ & NS & - \\
\hline Interactive effect of $\mathrm{Mg}_{\operatorname{exg} 200 \mu \mathrm{M}} \times \mathrm{Mg}_{\text {end }}$ & NS & - \\
\hline Interactive effect of $\mathrm{Mg}_{\text {exg } 200 \mu \mathrm{M}} \times \mathrm{V}_{\text {end }} \times \mathrm{Mg}_{\text {end }}$ & NS & - \\
\hline
\end{tabular}
toward interaction

Character of interaction revealed or character of a trend 
TABLE 2: Continued.

\begin{tabular}{|c|c|c|}
\hline \multicolumn{2}{|l|}{ Three-way ANOVA analysis ${ }^{\mathrm{a}}$} & $\begin{array}{c}\text { Character of interaction revealed or character of a trend } \\
\text { toward interaction }\end{array}$ \\
\hline \multicolumn{3}{|l|}{ LPO modified by $\mathrm{Mg}_{\operatorname{exg} 400 \mu \mathrm{M}}$} \\
\hline Main effect of $\mathrm{V}_{\text {end }}$ & $F=41.824, P=0.000$ & - \\
\hline Main effect of $\mathrm{Mg}_{\text {end }}$ & $F=53.944, P=0.000$ & - \\
\hline Interactive effect of $\mathrm{V}_{\text {end }} \times \mathrm{Mg}_{\text {end }}$ & $F=10.024, P=0.002$ & Antagonistic $^{\mathrm{b}}$ \\
\hline Main effect of $\mathrm{Mg}_{\operatorname{exg} 400 \mu \mathrm{M}}$ & $F=10.024, P=0.002$ & - \\
\hline Interactive effect of $\mathrm{Mg}_{\operatorname{exg} 400 \mu \mathrm{M}} \times \mathrm{V}_{\text {end }}$ & NS & - \\
\hline Interactive effect of $\mathrm{Mg}_{\operatorname{exg} 400 \mu \mathrm{M}} \times \mathrm{Mg}_{\text {end }}$ & NS & - \\
\hline Interactive effect of $\mathrm{Mg}_{\text {exg } 400 \mu \mathrm{M}} \times \mathrm{V}_{\text {end }} \times \mathrm{Mg}_{\text {end }}$ & NS & - \\
\hline \multicolumn{3}{|c|}{$\begin{array}{l}\mathrm{V}_{\text {end }} \text { and } \mathrm{Mg}_{\text {end }} \text { : endogenous } \mathrm{V}\left(\mathrm{NaVO}_{3}, \mathrm{SMV}\right) \text { and } \mathrm{Mg}\left(\mathrm{MgSO}_{4}, \mathrm{MS}\right) \text { which were received in combination for } 18 \text { weeks; } \mathrm{Fe}_{\text {exg }}, \mathrm{V}_{\text {exg }}, \mathrm{Mg}_{\text {exg }}: \text { exogenous Fe } \\
\left(\mathrm{FeSO}_{4}\right), \mathrm{V}\left(\mathrm{NaVO}_{3}\right) \text { and } \mathrm{Mg}\left(\mathrm{MgSO}_{4}\right) \text { added to liver supernatants obtained from the SMV-MS-coadministered rats. } \\
{ }^{2} \text { Data are presented as } F \text { values and the levels of significance }(P) \text {. NS: no significant effect. }\end{array}$} \\
\hline \multicolumn{3}{|c|}{$\begin{array}{l}\mathrm{b}^{\mathrm{b}} \text { The effect of } \mathrm{V}_{\text {end }} \text { and } \mathrm{Mg}_{\text {end }} \text { in combination in the presence of } \mathrm{Fe}_{\operatorname{exg} 30 \mu \mathrm{M}} \text { or } \mathrm{V}_{\operatorname{exg} 100,200,400 \mu \mathrm{M}} \text { or } \mathrm{Mg}_{\operatorname{exg} 100,200,400 \mu \mathrm{M}}<\text { sum of the effects of } \mathrm{V}_{\text {end }} \text { and } \mathrm{Mg}_{\text {end }} \\
\text { alone in the presence of } \mathrm{Fe}_{\operatorname{exg} 30 \mu \mathrm{M}} \text { or } \mathrm{V}_{\operatorname{exg} 100,200,400 \mu \mathrm{M}} \text { or } \mathrm{Mg}_{\operatorname{exg} 100,200,400 \mu \mathrm{M}} \text { (antagonistic interaction). }\end{array}$} \\
\hline \multirow{3}{*}{\multicolumn{3}{|c|}{ 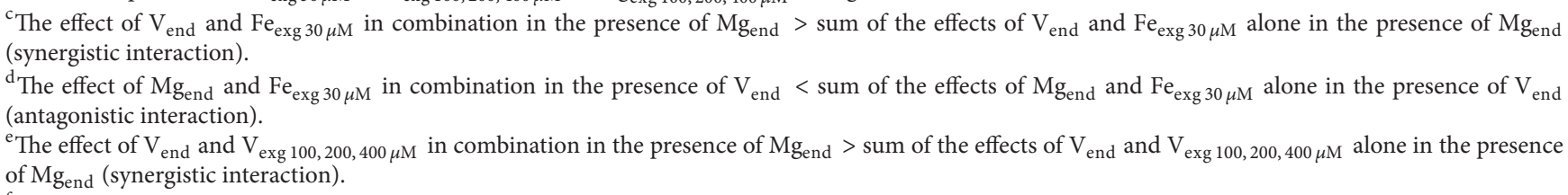 }} \\
\hline & & \\
\hline & & \\
\hline \multicolumn{3}{|c|}{$\begin{array}{l}\mathrm{f}_{T} \text { The effect of } \mathrm{Mg}_{\text {end }} \text { and } \mathrm{V}_{\text {exg } 100,200,400 \mu \mathrm{M}} \text { in combination in the presence of } \mathrm{V}_{\text {end }}<\text { sum of the effects of } \mathrm{Mg}_{\text {end }} \text { and } \mathrm{V}_{\text {exg } 100,200,400 \mu \mathrm{M}} \text { alone in the presence } \\
\text { of } \mathrm{V}_{\text {end }} \text { (antagonistic interaction). }\end{array}$} \\
\hline
\end{tabular}

$[36,42]$. The changes in the fluid and food intake and in the body weight gain in rats after SMV intoxication had already been discussed [43].

As we expected, V (as SMV) enhanced LPO (Figures 1(a) and 3(a)). The elevated level of LPO in the liver of rats after intoxication with SMV or ammonium metavanadate (AMV) and in LS incubated with sodium vanadate in the in vitro system was also reported by other investigators [4446]. A strong correlation between the induction of LPO and hepatotoxicity and the inhibition of both processes in parallel by antioxidants, suggesting a causative role for LPO in Vinduced hepatotoxicity, was observed as well [47].

The performed analysis allowed us to conclude that the increase in the MDA production observed in LS IV (Group IV) in the presence of $\mathrm{Fe}_{\mathrm{exg}} 30 \mu \mathrm{M}$ or $\mathrm{V}_{\text {exg } 100,200,400 \mu \mathrm{M}}$ (Figure 3(a)) was not only a consequence of the independent action of both elements but it also resulted from the synergistic interactions between $\mathrm{Fe}_{\text {exg }}$ and $\mathrm{V}_{\text {end }}$ and between $\mathrm{V}_{\text {end }}$ and $\mathrm{V}_{\text {exg }}$ (Table 2). The same interactive effects were found by us previously [11]. This is not surprising, as both elements may intensify LPO [48].

In turn, the incubation of LS II, III, and IV with $\mathrm{Mg}_{\text {exg 100, 200, } 400 \mu \mathrm{M}}$ did not significantly alter the MDA level, compared with spontaneously generated MDA, and only in LS I was a stimulating action of $\mathrm{Mg}$ on the hepatic MDA formation demonstrated (Figure 3(b)). The stimulating effect of $\mathrm{Mg}$ on the hepatic MDA production was also observed by us previously [11].

On the other hand, the present findings clearly demonstrated that the male Wistar rats receiving SMV in combination with MS (Group IV) for 18 weeks had a significantly lowered spontaneous MDA level than those exposed to
SMV (Group II), in which the hepatic spontaneous MDA generation was markedly higher, compared with that found in the control (Group I) and MS-supplemented animals (Group III) (Figure 2(a)). The results obtained from the two-way ANOVA analysis allowed us to conclude that the protective impact of $\mathrm{Mg}$ on reduction of the SMV-stimulated hepatic MDA generation during the 18-week combined SMV and MS administration resulted from the independent action of $\mathrm{Mg}_{\text {end }}$ and from its antagonistic interaction with $\mathrm{V}_{\text {end }}$ (Table 1). Unfortunately, when the rats were supplemented with MS during the shorter 12-week SMV exposure, we did not demonstrate any significant fall in the spontaneously generated MDA in the liver, compared with that found in SMV-intoxicated rats [11]. We may suppose that the differences in the duration of the experimental period might be, at least partly, the cause of the discrepancies observed.

In addition, the results of the three-way ANOVA analysis also allowed us to state that the limitation in the increase in the MDA production in LS IV incubated with $\mathrm{Fe}_{\operatorname{exg}} 30 \mu \mathrm{M}$ or $\mathrm{V}_{\text {exg 100, 200, } 400 \mu \mathrm{M}}$, compared with LS II (Figures 2(b)2(e)), might be associated with the antagonistic interaction of $\mathrm{Mg}_{\text {end }}$ with $\mathrm{Fe}_{\text {exg }}$ and $\mathrm{V}_{\text {exg }}$ (Table 2). Neither the antagonistic $\mathrm{V}_{\text {end }} \times \mathrm{Mg}_{\text {end }}, \mathrm{Fe}_{\text {exg }} \times \mathrm{Mg}_{\text {end }}$, and $\mathrm{Mg}_{\text {end }} \times \mathrm{V}_{\text {exg }}$ interactions nor the three-way interaction $(\mathrm{Fe} \times \mathrm{V} \times \mathrm{Mg})($ Table 2$)$ had been observed by us previously [11].

An important new finding of the study is that the independent action of $\mathrm{Mg}_{\text {end }}$ was a major effect responsible for suppression of the spontaneously formed MDA in the liver of rats supplemented with MS during the SMV exposure (Table 1). We cannot exclude that the antiradical activity of $\mathrm{Mg}$ might underlie, at least in part, its beneficial effect [28, 49-51]. The effect of $\mathrm{Mg}$ on some antioxidants appears 
also worthy of inquiry $[31,52]$. Therefore, further work is necessary to explain precisely the mechanism(s) responsible for the beneficial action of $\mathrm{Mg}$ in the 18-week conditions of the SMV-MS coadministration.

The $\mathrm{V}_{\text {end }} \times \mathrm{Mg}_{\text {end }}$ antagonistic interaction also played a significant role in the reduction of the SMV-induced spontaneous LPO in the liver of the SMV-MS-coadministered rats (Table 1). The $\mathrm{V} \times \mathrm{Mg}$ interactions investigated in in vivo and in vitro conditions are still little known, and only single reports about this issue have appeared in the literature [38, 53, 54]. Recently Sánchez et al. [55] showed that the interactions between $\mathrm{V}$ and $\mathrm{Mg}$ might occur in the rats' digestive and renal systems. The antagonistic character of the interaction revealed between $\mathrm{V}_{\text {end }}$ and $\mathrm{Mg}_{\text {end }}$ in our experimental conditions requires additional analyses. This seems to be important especially for extending the knowledge of the mechanism of the vanadate effect on organisms and the potential role of $\mathrm{Mg}$ in prevention of $\mathrm{V}$ toxicity.

\section{Conclusion}

To the best of our knowledge, the current report is the first demonstration of the protective action of $\mathrm{Mg}$ against the prooxidant potential of $\mathrm{V}$ revealed in a rat model. The study has clearly demonstrated that the 18-week supplementation of male Wistar rats with $\mathrm{Mg}$ (as MS) during the exposure to $\mathrm{V}$ (as SMV) may protect against V-induced hepatic LPO. The study provides evidence that the beneficial influence of $\mathrm{Mg}$ on limitation of the increase in the hepatic MDA generation during the 18-week SMV intoxication may result from the independent action of $\mathrm{Mg}$ and from its antagonistic interaction with V. However, further studies are needed to explain the exact mechanism(s) accounting for the protective effect of $\mathrm{Mg}$ against the SMV-induced OS in our experimental conditions. The results obtained seem to suggest that a proper $\mathrm{Mg}$ intake for a specific time period in the conditions of SMV exposure may prevent V-stimulated LPO in the liver.

The present study has also shown the degree to which the independent action of the elements used ( $\mathrm{V}, \mathrm{Mg}$, and $\mathrm{Fe}$ ) and their mutual interactions may modify the hepatic MDA production. Simultaneously, it has confirmed that $\mathrm{Mg}$ is able to promote LPO in certain conditions by revealing its stimulating action on the explored free radical process in the in vitro system.

\section{Abbreviations}

$\mathrm{Mg}_{\text {end }}: \mathrm{Mg}$ (as MS) administered to rats endogenously

$\mathrm{V}_{\text {end }}$ : $\mathrm{V}$ (as SMV) administered to rats endogenously

$\mathrm{Mg}_{\text {exg }}: \mathrm{Mg}\left(\right.$ as $\mathrm{MgSO}_{4}$ ) added exogenously to liver supernatants (LS)

$\mathrm{V}_{\text {exg }}: \mathrm{V}\left(\right.$ as $\mathrm{NaVO}_{3}$ ) added exogenously to liver supernatants (LS)

$\mathrm{Fe}_{\text {exg }}: \mathrm{Fe}\left(\right.$ as $\mathrm{FeSO}_{4}$ ) added exogenously to liver supernatants (LS).

\section{Conflict of Interests}

The authors declare that they have no conflict of interests.

\section{References}

[1] J. E. Klaunig, Y. Xu, J. S. Isenberg et al., "The role of oxidative stress in chemical carcinogenesis," Environmental Health Perspectives, vol. 106, supplement 1, pp. 289-295, 1998.

[2] G. Bartosz, Druga Twarz Tlenu. Wolne Rodniki w Przyrodzie, Wydawnictwo Naukowe PWN, Warszawa, Poland, 2004.

[3] E. Niki, "Lipid peroxidation: physiological levels and dual biological effects," Free Radical Biology and Medicine, vol. 47, no. 5, pp. 469-484, 2009.

[4] E. Niki, Y. Yoshida, Y. Saito, and N. Noguchi, "Lipid peroxidation: mechanisms, inhibition, and biological effects," Biochemical and Biophysical Research Communications, vol. 338, no. 1, pp. 668-676, 2005.

[5] S. Srivastava, B. Chandrasekar, A. Bhatnagar, and S. D. Prabhu, "Lipid peroxidation-derived aldehydes and oxidative stress in the failing heart: role of aldose reductase," American Journal of Physiology, vol. 283, no. 6, pp. H2612-H2619, 2002.

[6] Z. H. Chen and E. Niki, "Two faces of lipid peroxidation products: the "Yin and Yang" principles of oxidative stress," Journal of Experimental and Integrative Medicine, vol. 1, no. 4, pp. 215-219, 2011.

[7] M. A. Altamirano-Lozano and M. E. Roldán-Reyes, "Genetic toxicology of vanadium compounds," in Vanadium in the Environment Part II: Health Effects, J. O. Nriagu, Ed., vol. 31, pp. 159-179, John Wiley \& Sons, New York, NY, USA, 1998.

[8] A. Goc, "Biological activity of vanadium compounds," Central European Journal of Biology, vol. 1, no. 3, pp. 314-332, 2006.

[9] J. O. Nriagu, Vanadium in the Environment. Health Effects, vol. 31, part 2, John Wiley \& Sons, New York, NY, USA, 1998.

[10] J. Z. Byczkowski and A. P. Kulkarni, "Oxidative stress and prooxidant biological effects of vanadium," in Vanadium in the Environment Part II: Health Effects, J. O. Nriagu, Ed., vol. 31, pp. 235-264, John Wiley \& Sons, New York, NY, USA, 1998.

[11] A. Ścibior, H. Zaporowska, and I. Niedźwiecka, "Lipid peroxidation in the liver of rats treated with $\mathrm{V}$ and/or $\mathrm{Mg}$ in drinking water," Journal of Applied Toxicology, vol. 29, no. 7, pp. 619-628, 2009.

[12] A. Ścibior, H. Zaporowska, and I. Niedźwiecka, "Lipid peroxidation in the kidney of rats treated with $\mathrm{V}$ and/or Mg in drinking water," Journal of Applied Toxiology, vol. 30, no. 5, pp. 487-496, 2010.

[13] N. H. Stacey and C. D. Klaassen, "Comparison of the effects of metals on cellular injury and lipid peroxidation in isolated rat hepatocytes," Journal of Toxicology and Environmental Health, vol. 7, no. 1, pp. 139-147, 1981.

[14] J. Donaldson and F. LaBella, "Prooxidant properties of vanadate in vitro on catecholamines and on lipid peroxidation by mouse and rat tissues," Journal of Toxicology and Environmental Health, vol. 12, no. 1, pp. 119-126, 1983.

[15] J. Donaldson, R. Hemming, and F. LaBella, "Vanadium exposure enhances lipid peroxidation in the kidney of rats and mice," Canadian Journal of Physiology and Pharmacology, vol. 63, no. 3, pp. 196-199, 1985.

[16] M. H. Oster, J. M. Llobet, J. L. Domingo, J. B. German, and C. L. Keen, "Vanadium treatment of diabetic Sprague-Dawley rats results in tissue vanadium accumulation and pro-oxidant effects," Toxicology, vol. 83, no. 1-3, pp. 115-130, 1993.

[17] K. Furuno, T. Suetsugu, and N. Sugihara, "Effects of metal ions on lipid peroxidation in cultured rat hepatocytes loaded with $\alpha$ linolenic acid," Journal of Toxicology and Environmental Health A, vol. 48, no. 2, pp. 121-129, 1996. 
[18] A. Soussi, F. Croute, J. P. Soleilhavoup, A. Kammoun, and A. El Feki, "Impact of green tea on oxidative stress induced by ammonium metavanadate exposure in male rats," Comptes Rendus, vol. 329, no. 10, pp. 775-784, 2006.

[19] S. S. Soares, H. Martins, R. O. Duarte et al., "Vanadium distribution, lipid peroxidation and oxidative stress markers upon decavanadate in vivo administration," Journal of Inorganic Biochemistry, vol. 101, no. 1, pp. 80-88, 2007.

[20] Y. Deng, H. Cui, X. Peng et al., "Dietary vanadium induces oxidative stress in the intestine of broilers," Biological Trace Element Research, vol. 145, pp. 52-58, 2012.

[21] J. Liu, H. Cui, X. Liu et al., "Dietary vanadium causes oxidative damage-induced renal and hepatic toxicity in broilers," Biological Trace Element Research, vol. 145, no. 2, pp. 189-200, 2012.

[22] T. Matsubara, S. Musat-Marcu, H. P. Misra, and N. S. Dhalla, "Protective effect of vanadate on oxyradical-induced changes in isolated perfused heart," Molecular and Cellular Biochemistry, vol. 153, no. 1-2, pp. 79-85, 1995.

[23] M. C. Cam, R. W. Brownsey, and J. H. McNeill, "Mechanisms of vanadium action: insulin-mimetic or insulin-enhancing agent?" Canadian Journal of Physiology and Pharmacology, vol. 78, no. 10, pp. 829-847, 2000.

[24] A. Bishayee, R. Karmakar, A. Mandal, S. N. Kundu, and M. Chatterjee, "Vanadium-mediated chemoprotection against chemical hepatocarcinogenesis in rats: haematological and histological characteristics," European Journal of Cancer Prevention, vol. 6, no. 1, pp. 58-70, 1997.

[25] P. S. Kanna, C. B. Mahendrakumar, B. N. Indira et al., "Chemopreventive effects of vanadium toward 1,2-dimethylhydrazineinduced genotoxicity and preneoplastic lesions in rat colon," Environmental and Molecular Mutagenesis, vol. 44, no. 2, pp. 113-118, 2004.

[26] T. Chakraborty, A. Chatterjee, M. G. Saralaya, D. Dhachinamoorthi, and M. Chatterjee, "Vanadium inhibits the development of 2-acetylaminofluorene-induced premalignant phenotype in a two-stage chemical rat hepatocarcinogenesis model," Life Sciences, vol. 78, no. 24, pp. 2839-2851, 2006.

[27] E. Niedworok, M. Wardas, M. Stec, and M. Dołowy, "Ocena procesu peroksydacji lipidów modyfikowanego jonami magnezu i etanolem w izolowanych hepatocytach szczura," Nowiny Lekarskie, vol. 71, no. 6, pp. 295-298, 2002.

[28] R. F. Regan, E. Jasper, Y. Guo, and S. S. Panter, “The effect of magnesium on oxidative neuronal injury in vitro," Journal of Neurochemistry, vol. 70, no. 1, pp. 77-85, 1998.

[29] Y. Yamaguchi, S. Kitagawa, M. Kunitomo, and M. Fujiwara, "Preventive effects of magnesium on raised serum lipid peroxide levels and aortic cholesterol deposition in mice fed an atherogenic diet," Magnesium Research, vol. 7, no. 1, pp. 31-37, 1994.

[30] H. Bariskaner, M. E. Ustun, A. Ak, A. Yosunkaya, H. B. Ulusoy, and M. Gurbilek, "Effects of magnesium sulfate on tissue lactate and malondialdehyde levels after cerebral ischemia," Pharmacology, vol. 68, no. 3, pp. 162-168, 2003.

[31] C. P. Hans, D. P. Chaudhary, and D. D. Bansal, "Effect of magnesium supplementation on oxidative stress in alloxanic diabetic rats," Magnesium Research, vol. 16, no. 1, pp. 13-19, 2003.

[32] N. Sahin, M. Onderci, K. Sahin, G. Cikim, and O. Kucuk, "Magnesium proteinate is more protective than magnesium oxide in heat-stressed quail," Journal of Nutrition, vol. 135, no. 7, pp. 1732-1737, 2005.
[33] C. Abad, A. Teppa-Garrán, T. Proverbio, S. Piñero, F. Proverbio, and R. Marín, "Effect of magnesium sulfate on the calciumstimulated adenosine triphosphatase activity and lipid peroxidation of red blood cell membranes from preeclamptic women," Biochemical Pharmacology, vol. 70, no. 11, pp. 1634-1641, 2005.

[34] A. C. Ariza, N. Bobadilla, C. Fernández, R. M. Muñoz-Fuentes, F. Larrea, and A. Halhali, "Effects of magnesium sulfate on lipid peroxidation and blood pressure regulators in preeclampsia," Clinical Biochemistry, vol. 38, no. 2, pp. 128-133, 2005.

[35] S. Shukla, V. Singh, and D. Joshi, "Modulation of toxic effects of organic mercury by different antioxidants," Toxicology International, vol. 14, no. 1, pp. 67-71, 2007.

[36] A. Ścibior, A. Adamczyk, D. Golłębiowska, and I. Niedźwiecka, "Effect of 12-week vanadate and magnesium co-administration on chosen haematological parameters as well as on some indices of iron and copper metabolism and biomarkers of oxidative stress in rats," Environmental Toxicology and Pharmacology, vol. 34, no. 2, pp. 235-252, 2012.

[37] J. L. Domingo, "Vanadium: a review of the reproductive and developmental toxicity," Reproductive Toxicology, vol. 10, no. 3, pp. 175-182, 1996.

[38] M. Matsuda, L. Mandarino, and R. A. DeFronzo, "Synergistic interaction of magnesium and vanadate on glucose metabolism in diabetic rats," Metabolism, vol. 48, no. 6, pp. 725-731, 1999.

[39] U.S. EPA (United States Environmental Protection Agency), "Drinking water advisory: consumer acceptability advice and health effects analysis on sulphate," EPA 822-R-03-007, February 2003.

[40] WHO (World Health Organization), "Sulfate in drinking water," Background Document For Development of WHO Guidelines For Drinking-Water Quality WHO/SDE/WSH/03.04/114, 2004.

[41] A. A. Gołubiew, E. I. Lublina, N. A. Tołokncew, and W. A. Fiłow, Toksykologia Ilościowa, Wydawnictwo Lekarskie PZWL, Warszawa, Poland, 1978.

[42] A. Ścibior and H. Zaporowska, "Effects of combined vanadate and magnesium treatment on erythrocyte antioxidant defence system in rats," Environmental Toxicology and Pharmacology, vol. 30, no. 2, pp. 153-161, 2010.

[43] A. Ścibior, H. Zaporowska, A. Wolińska, and J. Ostrowski, "Antioxidant enzyme activity and lipid peroxidation in the blood of rats co-treated with vanadium $\left(\mathrm{V}^{+5}\right)$ and chromium $\left(\mathrm{Cr}^{+3}\right)$," Cell Biology and Toxicology, vol. 26, no. 6, pp. 509-526, 2010.

[44] M. Younes, M. Albrecht, and C. F. Siegers, "Lipid peroxidation and lysosomal enzyme release induced by vanadate in vitro," Research Communications in Chemical Pathology and Pharmacology, vol. 43, no. 3, pp. 487-495, 1984.

[45] M. Elfant and C. L. Keen, "Sodium vanadate toxicity in adult and developing rats. Role of peroxidative damage," Biological Trace Element Research, vol. 14, no. 3, pp. 193-208, 1987.

[46] E. Russanov, H. Zaporowska, E. Ivancheva, M. Kirkova, and S. Konstantinova, "Lipid peroxidation and antioxidant enzymes in vanadate-treated rats," Comparative Biochemistry and Physiology C, vol. 107, no. 3, pp. 415-421, 1994.

[47] M. Younes and O. Strubelt, "Vanadate-induced toxicity towards isolated perfused rat livers: the role of lipid peroxidation," Toxicology, vol. 66, no. 1, pp. 63-74, 1991.

[48] N. H. Stacey and H. Kappus, "Comparison of methods of assessment of metal-induced lipid peroxidation in isolated rat hepatocytes," Journal of Toxicology and Environmental Health, vol. 9, no. 2, pp. 277-285, 1982. 
[49] L. A. Garcia, S. C. Dejong, S. M. Martin, R. S. Smith, G. R. Buettner, and R. E. Kerber, "Magnesium reduces free radicals in an in vivo coronary occlusion- reperfusion model," Journal of the American College of Cardiology, vol. 32, no. 2, pp. 536-539, 1998.

[50] I. T. Mak, A. M. Komarov, J. H. Kramer, and W. B. Weglicki, "Protective mechanisms of Mg-gluconate against oxidative endothelial cytotoxicity," Cellular and Molecular Biology, vol. 46, no. 8, pp. 1337-1344, 2000.

[51] S. B. Murthi, R. M. Wise, W. B. Weglicki, A. M. Komarov, and J. $\mathrm{H}$. Kramer, "Mg-gluconate provides superior protection against postischemic dysfunction and oxidative injury compared to Mg-sulfate," Molecular and Cellular Biochemistry, vol. 245, no. 1-2, pp. 141-148, 2003.

[52] B. Matkovics, I. Kiss, and S. A. Kiss, "The activation by magnesium treatment of anti-oxidants eliminating the oxygen free radicals in drosophila melanogaster in vivo," Magnesium Research, vol. 10, no. 1, pp. 33-38, 1997.

[53] P. J. Romero, "Synergistic activation of the human red cell calcium ATPase by magnesium and vanadate," Biochimica et Biophysica Acta, vol. 1143, no. 1, pp. 45-50, 1993.

[54] P. J. Romero and A. F. Rega, "Effects of magnesium plus vanadate on partial reactions of the $\mathrm{Ca}^{2+}$-ATPase from human red cell membranes," Biochimica et Biophysica Acta, vol. 1235, no. 1, pp. 155-157, 1995.

[55] C. Sánchez, M. Torres, M. C. Bermúdez-Peña et al., "Bioavailability, tissue distribution and hypoglycaemic effect of vanadium in magnesium-deficient rats," Magnesium Research, vol. 24, no. 4, pp. 196-208, 2011. 


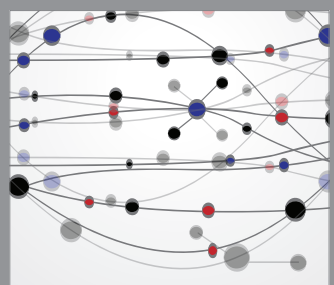

The Scientific World Journal
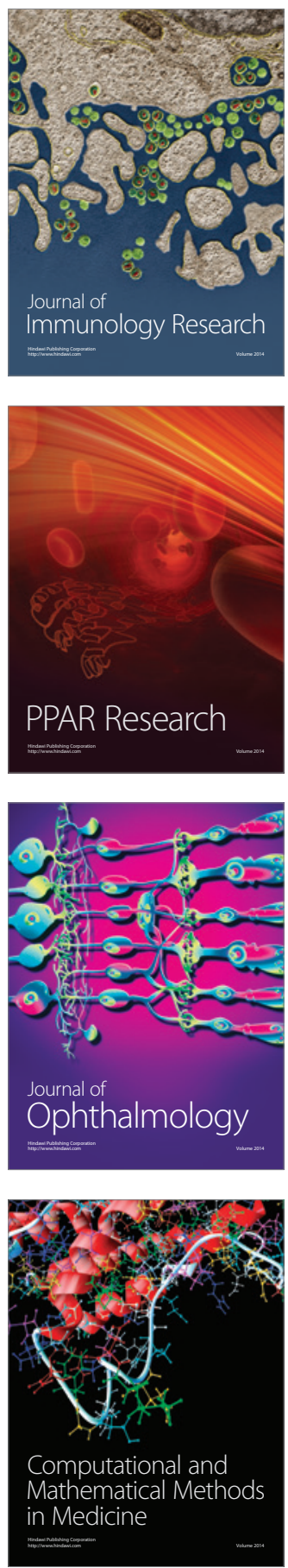

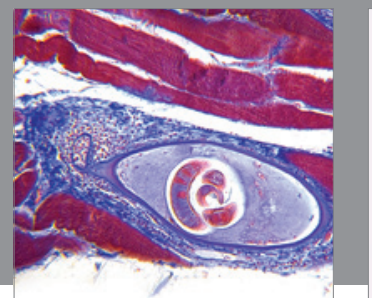

Gastroenterology

Research and Practice
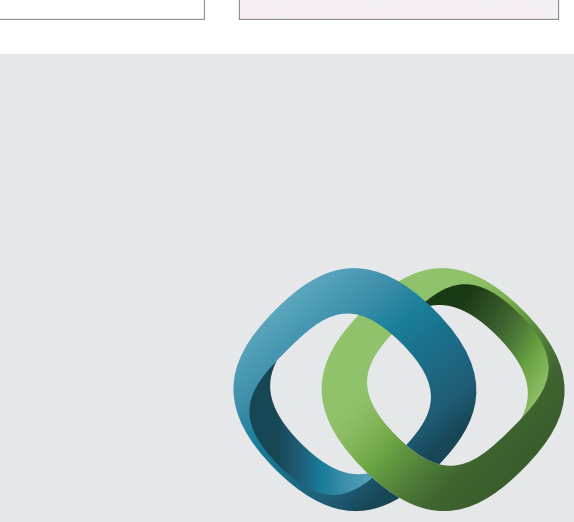

\section{Hindawi}

Submit your manuscripts at

http://www.hindawi.com
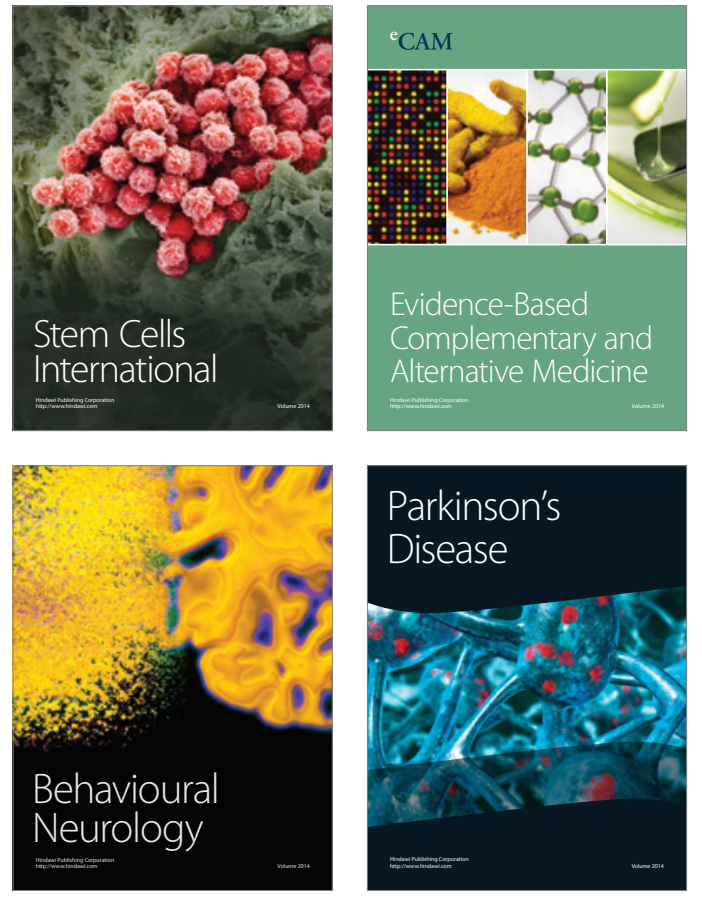
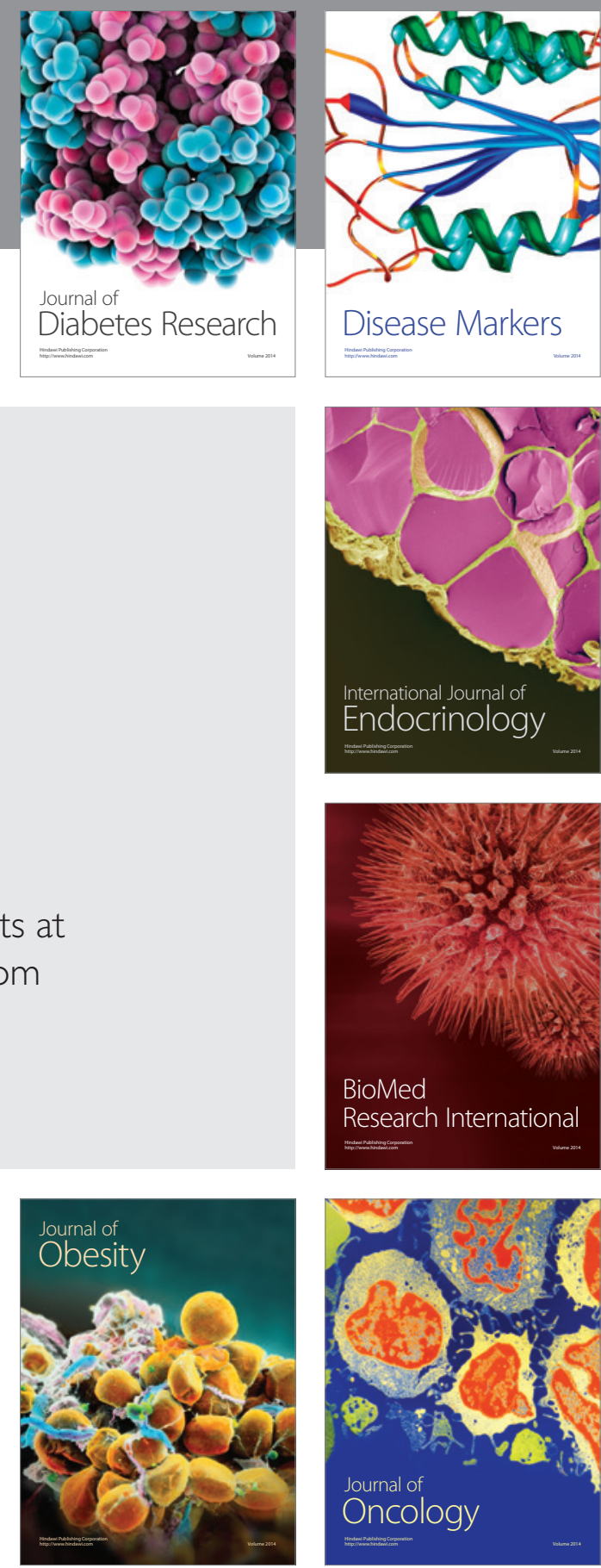

Disease Markers
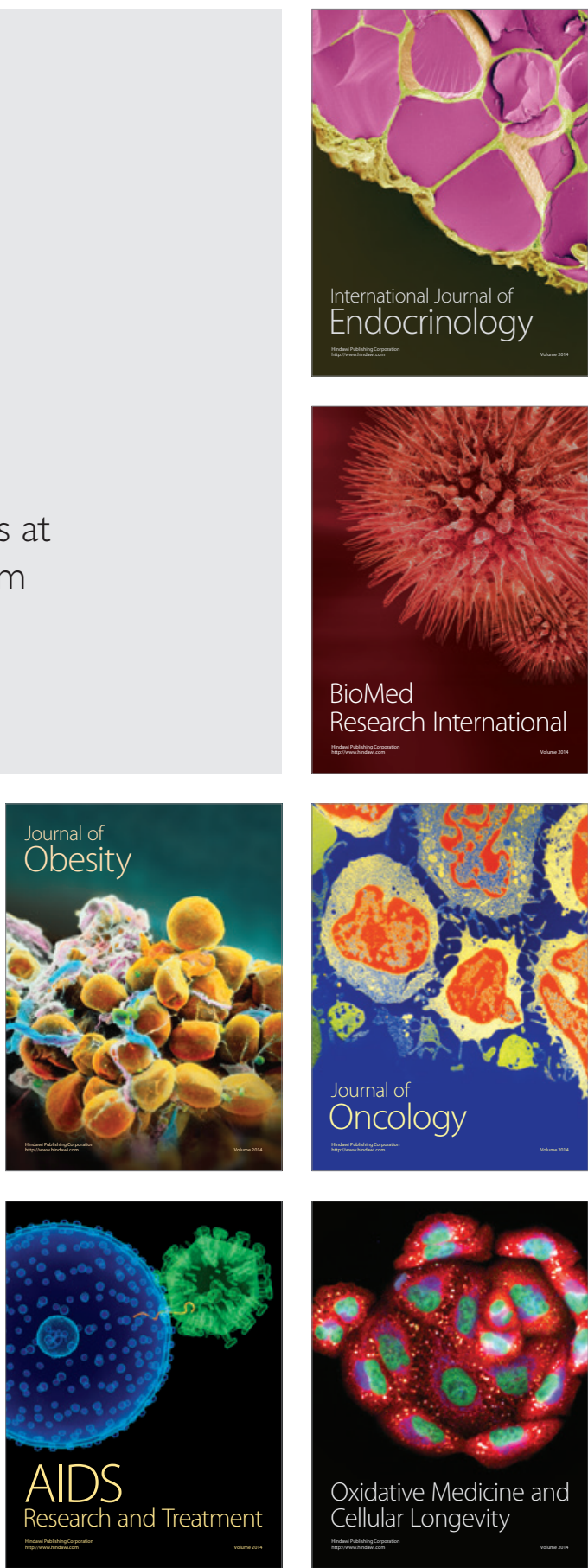